\title{
Curvularin produced by endophytic Cochliobolus sp. G2-20 isolated from Sapindus saponaria L. and evaluation of biological activity
}

\author{
Daniel Ataides ${ }^{1}$, João Alencar Pamphile ${ }^{1 *}$, Adriana Garcia ${ }^{1}$, Marcos Alessandro dos Santos Ribeiro ${ }^{1}$, Julio Cesar Polonio ${ }^{1}$, \\ Maria Helena Sarragiotto ${ }^{2}$, Edmar Clemente ${ }^{3+}$ \\ ${ }^{1}$ Department of Biotechnology, Genetics and Cell Biology, Laboratory of Microbial Biotechnology, State University of Maringá, Maringá, Brazil. \\ ${ }^{2}$ Department of Chemistry, Laboratory of Chemical Synthesis and Natural Products, State University of Maringá, Maringá, Brazil. \\ ${ }^{3}$ Department of Chemistry, Laboratory of Food Biochemistry, State University of Maringá, Maringá, Brazil.
}

\section{ARTICLE INFO \\ Received on: $17 / 05 / 2018$ \\ Accepted on: 10/10/2018 \\ Available online: 30/12/2018 \\ Key words: \\ Antimicrobial, bioactive \\ compounds, endophyte, \\ NMR, secondary metabolites.}

\begin{abstract}
Endophytic fungi are organisms that live within intercellular tissues of healthy plants and are able to produce a huge variety of secondary metabolites with a broad spectrum of use. The endophytic fungus Cochliobolus sp. G2-20, still little known, and can effectively produce bioactive compounds. It was isolated from Sapindus saponaria L., a plant with antimicrobial effects. The aim of this study was to obtain secondary metabolites from the fungus Cochliobolus sp. G2-20 isolated from medicinal plant $S$. saponaria $\mathrm{L}$., to characterize the main compounds of crude extract of secondary metabolites and to evaluate their antimicrobial activity. The endophytic fungus was grown in potato dextrose broth for 7 days without agitation at a temperature of $28^{\circ} \mathrm{C}$. It was used for the filtration followed by centrifugation to the obtainment of broth without mycelium. The supernatant was partitioned with ethyl acetate resulting in an extract that was fractionated and used to identify metabolite compounds. After chromatographic procedures, the fractions were analyzed by ${ }^{1} \mathrm{H}(300 \mathrm{MHz})$ and ${ }^{13} \mathrm{C}(75.5 \mathrm{MHz})$ nuclear magnetic resonance for identification of the chemical components. Curvularin was identified from fraction D being the main substance produced by Cochliobolus sp. G2-20, and had an inhibitory effect on growth of the fungi Moniliophthora perniciosa, Didymella bryoniae, and Fusarium solani forma specialis (f. sp.) glycines, and bacteria Micrococcus luteus, Xanthomonas axonopodis pv. phaseoli, Staphylococcus aureus, Escherichia coli, and Enterococcus hirae. The extract of the endophytic fungus Cochliobolus sp. showed antibacterial and antifungal activities, thus confirming its potential for biotechnological applications.
\end{abstract}

\section{INTRODUCTION}

There are several interactions types between fungal and plant host as epiphytic, endophytic, pathogenic, and saprophytic (Manamgoda et al., 2011). Hence, it could be observed in the Cochliobolus species (as so Anamorphs), the endophytic association to various plant hosts as Triticum aestivum (Larran et al., 2007), Piptadenia adiantoides (Campos et al., 2008), Hevea

\footnotetext{
${ }^{*}$ Corresponding Author

João Alencar Pamphile, Department of Biotechnology, Genetics and Cell Biology, Laboratory of Microbial Biotechnology, State University of Maringá, Maringá, Brazil.E-mail: prof.pamphile@gmail.com; japamphile@uem.br

†n memoriam.
}

brasiliensis (Gazis and Chaverria, 2010), Luehea divaricata (Bernardi-Wenzel et al., 2010), S. saponaria (Garcia et al., 2012a), and Piper hispidum (Orlandelli et al., 2012) with isolation frequency less than $10 \%$, which is lower than the emergence of endophytes in others vegetables (Suryanarayanan et al., 2002; Thongkantha et al., 2008).

The bioactive compounds as antimicrobial metabolites produced by Cochliobolus species are poorly described. However, the combination of plant and endophytic microorganisms has different metabolites in response to pathogens than the plant without endophytes or the endophytes alone. Therefore, antibacterial and antifungal activities tests are routinely conducted to identify the biological potential of this endophyte in controlling the known pathogens from plants and humans (Chagas et al., 2015). 
Endophytic microorganisms are fungi and bacteria that inhabit inter- or intracellular spaces of tissues or plant-organs at least one phase of plant life cycle. These plant-endophyte interactions needs of a complex establishment of metabolic and genetic factors to provide simbiotics and/or mutualistic relationships between organisms (Kusari et al., 2012). This balanced interaction could produce several compounds that can be protective effects in the hosts against insects, pathogens, can reduce the herbivory, and others biotic and abiotic factors (Arnold et al., 2003; Azevedo et al., 2000; Firáková et al., 2007; Kaneko et al., 2010; Mejía et al., 2008; Terhonen et al., 2016). Thus, endophytic microorganisms have an economic and ecological potential as exploration sources of bioactive compounds with greater viability when compared with biocompounds from plants (Romão-Dumaresq et al., 2016; Schulz et al., 2002; Strobel et al., 2004; Yan et al., 2017).

This study was isolated, identified the chemical components, and evaluated the antifungal and antibacterial activity of metabolic fractions of an extract from Cochliobolus sp. G2-20 isolated from $S$. saponaria.

\section{MATERIALS AND METHODS}

\section{Fungal material}

The endophytic fungus Cochliobolus sp., strain G220 (ITS1-5,8S-ITS2 Genbank accession number: GQ461566.1) was isolated from inside the leaf tissue of $S$. saponaria by Garcia et al. (2012a). This strain belongs to the Laboratory of Microbial Biotechnology, State University of Maringá, Paraná, Brazil.

\section{Fermentation and compound extraction}

In accordance with the previous results of Cochliobolus sp. G2-20 (Garcia et al., 2012a), the endophyte grown in petri dishes with potato-dextrose agar (Himedia, Mumbai, India) at $28^{\circ} \mathrm{C}$, approximately 7 days before transferal to broth. To isolate secondary metabolites, the method used by Rukachaisirikul et al. (2008) and Flores et al. (2013) was followed with some modifications as: the incubation time was 7 days at $28^{\circ} \mathrm{C}$ under stationary conditions; after remove the cellular debris by centrifugation step, the supernatant was partitioned twice with ethyl acetate at a ratio of 1:1 $(100 \mathrm{ml}$ of solvent in $100 \mathrm{ml}$ of fermented medium). Therefore, the solvent was evaporated in the rotary evaporator (Marconi MA 120) at $40^{\circ} \mathrm{C}$, resulting in the crude extract.

\section{Purification and identification of chemical constituents}

The procedures of chemical analyzes were adapted from Specian et al. (2012) and Flores et al. (2013). The chemical profile of extract was evaluated by thin layer chromatography (TLC). Thereafter, a liquid chromatographic column was used to separate compounds using a column of silica gel LH-20 as the stationary phase, and methanol $(\mathrm{MeOH})$ as the mobile phase. This process resulted in 80 fractions (numbered 1-80). These fractions were also analyzed by TLC for grouping by similarity resulting in 11 final fractions with different weight: A $(6.9 \mathrm{mg}), \mathrm{B}(4.6 \mathrm{mg}), \mathrm{C}_{\text {crystal }}$ (7.2 mg), $\mathrm{C}_{\mathrm{s}}(101.1 \mathrm{mg}), \mathrm{D}_{\mathrm{s}}(62.5 \mathrm{mg}), \mathrm{D}(7.7 \mathrm{mg}), \mathrm{EF}(43.5 \mathrm{mg})$, $\mathrm{H}$ (42.8 mg), I (15.1 mg), and JK (10.2 mg). The $\mathrm{C}_{\text {crystal }}, \mathrm{C}_{\mathrm{s}}$, and $\mathrm{D}_{\mathrm{s}}$ terminologies are due to the formation of crystals or of a supernatant when resuspended with ethyl acetate. Fractions $\mathrm{C}_{\text {crystal }}, \mathrm{D}, \mathrm{EF}$, and I were chosen for analysis by nuclear magnetic resonance (NMR) of ${ }^{1} \mathrm{H}(300 \mathrm{MHz})$ and ${ }^{13} \mathrm{C}(75.5 \mathrm{MHz})$ for elucidating the chemical structures present in the fractions. These fractions were chosen, because they had greater purity when analyzed by TLC.

\section{Antibacterial assay}

Human pathogenic bacteria used were Micrococcus luteus (ATCC 9341), Salmonella typhi (ATCC 19430), Escherichia coli (ATCC 25922), Staphylococcus aureus (ATCC 25923), and Enterococcus hirae (ATCC 1227). The phytopathogenic bacterium used was Xanthomonas axonopodis pv. phaseoli from the collection of pathogenic microorganisms of Cenargen Embrapa Genetic Resources and Biotechnology.

The bacteria grew for 24 hours in Luria-Bertani (LB) broth at $37^{\circ} \mathrm{C}$, except for $X$. axonopodis that grown at $28^{\circ} \mathrm{C}$. The cultures were adjusted to a concentration of $10^{6}$ cells $/ \mathrm{ml}$, as described by Sambrook and Russell (2001). The antibacterial assay of subfractions $\mathrm{C}_{\text {crystal }}, \mathrm{D}, \mathrm{EF}$, and I was performed in accordance with Flores et al., (2013). Tetracycline (Sigma) at $50 \mu \mathrm{g} \mathrm{ml}^{-1}$ was used as positive control.

\section{Antifungal assay}

The antifungal test was performed according to GomesFigueiredo et al. (2007) with some modifications described by Flores et al. (2013). The pathogenic fungi used were Sclerotinia sclerotiorum, Fusarium solani f. sp. glycines, Moniliophthora perniciosa, Colletotrichum gloeosporioides, and Didymella bryoniae which belong to the collection of microorganisms at the Microbial Biotechnology Laboratory, State University of Maringá, Paraná, Brazil, and they were tested the subfractions $\mathrm{C}_{\text {crystal }}, \mathrm{D}, \mathrm{EF}$, and I. The negative controls were water and $\mathrm{MeOH}$ and the positive control used were the fungicide Derosal plus ${ }^{\circledR}$ (carbendazim + thiram, Bayer) at a dilution of $10^{-1}$.

\section{Statistical analysis}

All experiments testing the antimicrobial activity were performed in triplicate and analyzed using a completely randomized design. The results were evaluated by the analysis of variance followed by Tukey's $(p<0.05)$ test for comparison of means. Sisvar v.5.3 was used for the analysis (Ferreira, 2011).

\section{RESULTS AND DISCUSSION}

Endophytic fungi and bacteria are a new source of bioactive molecules, producing different kinds of metabolites as

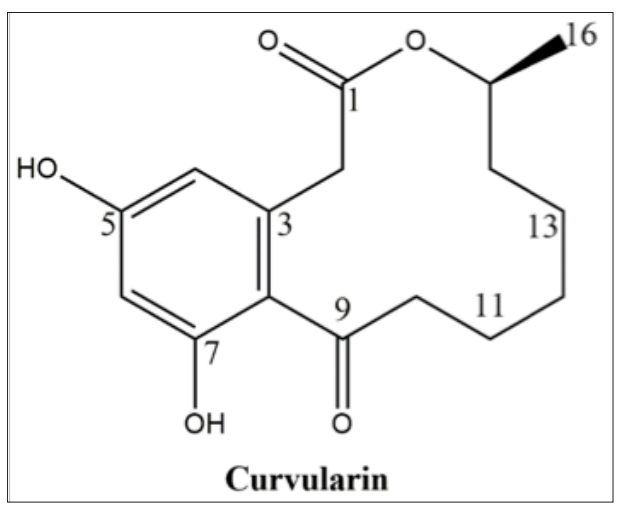

Figure 1. The molecular structure of curvularin, $\mathrm{C}_{16} \mathrm{H}_{20} \mathrm{O}_{5}$. 
potential pharmaceutical drugs as those produced by plants and marine organisms (Firáková et al., 2007; Ramasamy et al., 2010).

Fraction D revealed a characteristic ${ }^{1} \mathrm{H}$ NMR spectrum. The NMR spectra of ${ }^{1} \mathrm{H}$ and ${ }^{13} \mathrm{C}$ were compared with the published data (Dong et al., 2014), allowing the identification of the major compound as curvularin (Fig. 1; Fig. 2A-F; and Table 1).

The curvularin extracted from fraction $\mathrm{D}$ present an ${ }^{13} \mathrm{C}$ NMR spectrum of $\delta 209.91$ (C, C-9), 172.90 (C, C-1), 161.41 (C,
C-5), 159.69 (C, C-7), 137.40 (C, C-3), 121.01 (C, C-8), 112.38 $(\mathrm{CH}, \mathrm{C}-4), 102.84(\mathrm{CH}, \mathrm{C}-6), 73.94(\mathrm{CH}, \mathrm{C}-15), 44.79\left(\mathrm{CH}_{2}\right.$, $\mathrm{C}-10), 40.86\left(\mathrm{CH}_{2}, \mathrm{C}-2\right), 32.13\left(\mathrm{CH}_{2}, \mathrm{C}-14\right), 27.87\left(\mathrm{CH}_{2}, \mathrm{C}-12\right)$, $25.80\left(\mathrm{CH}_{2}, \mathrm{C}-13\right), 24.00\left(\mathrm{CH}_{2}, \mathrm{C}-11\right)$, and $20.64\left(\mathrm{CH}_{3}, \mathrm{CH}_{3}-15\right)$, very similar to the compound curvularin (Dong et al., 2014; Ye et al., 2015) (Table 1).

Curvularin is a macrolide antibiotic produced by a large number of species of fungi from several genera, among which
A

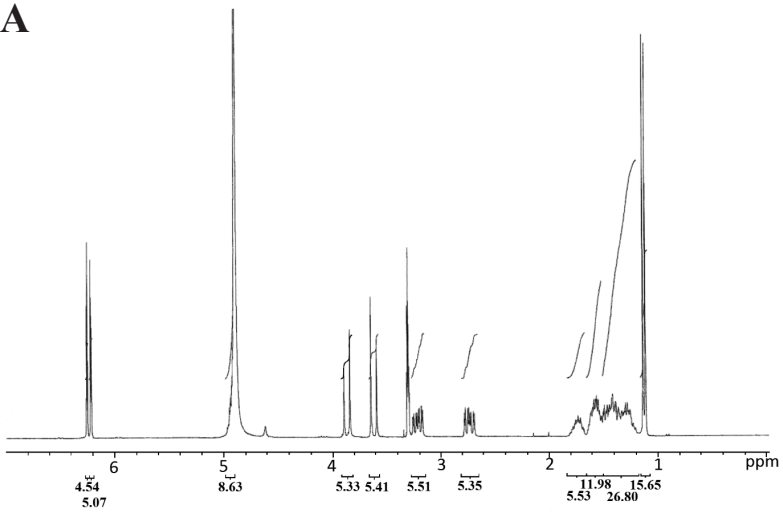

C
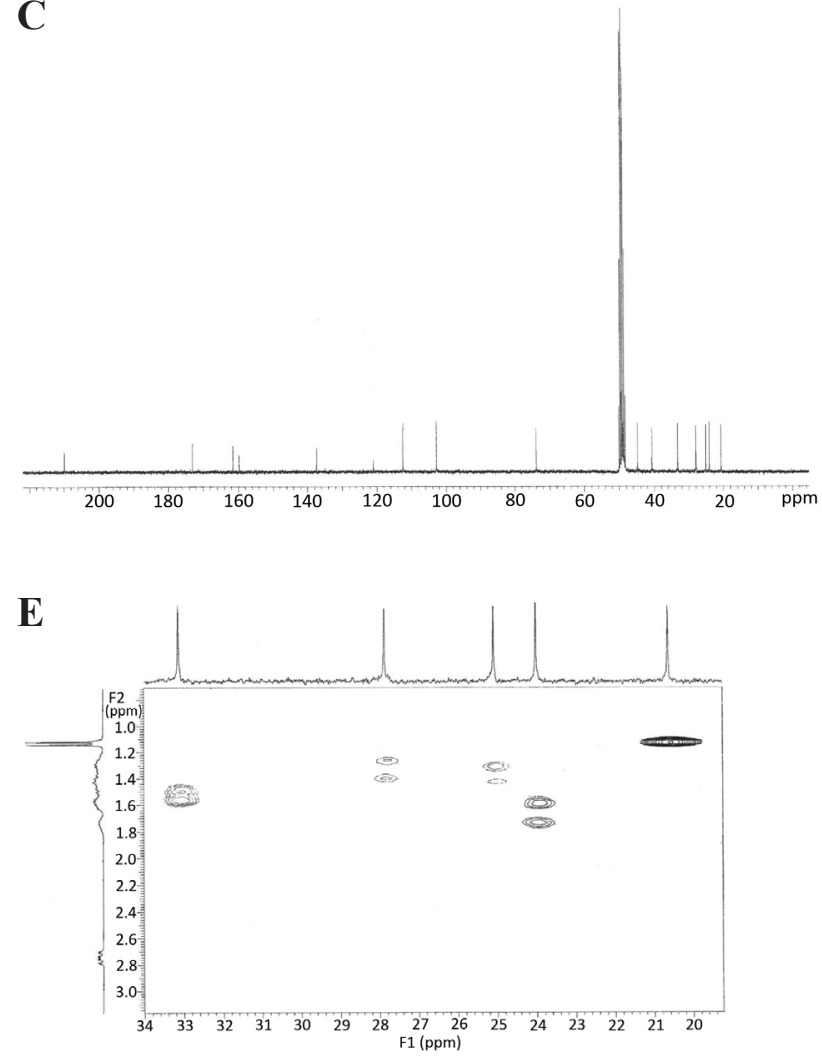

B

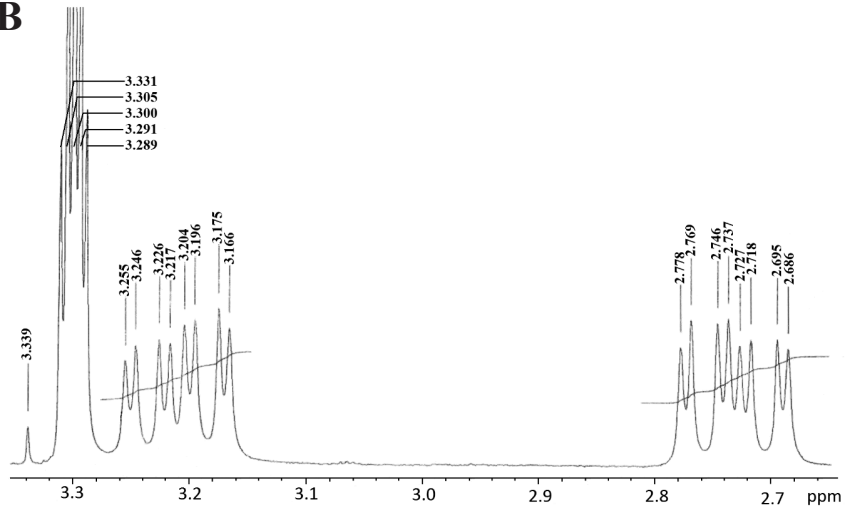

D

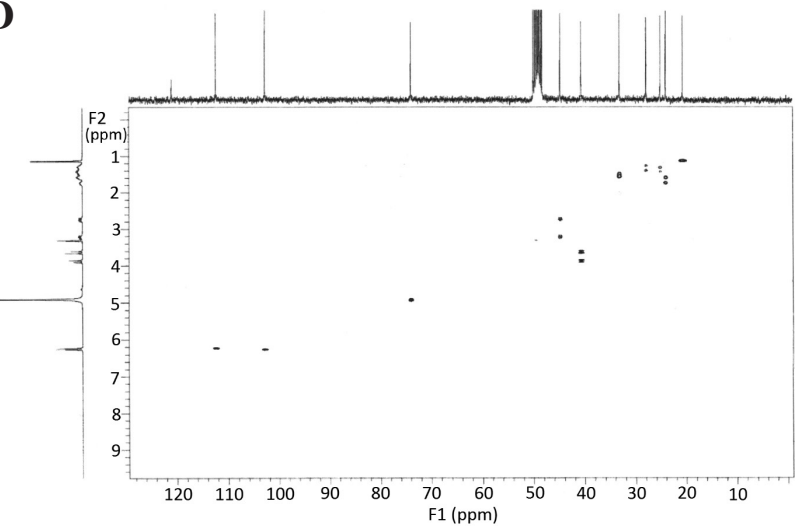

F
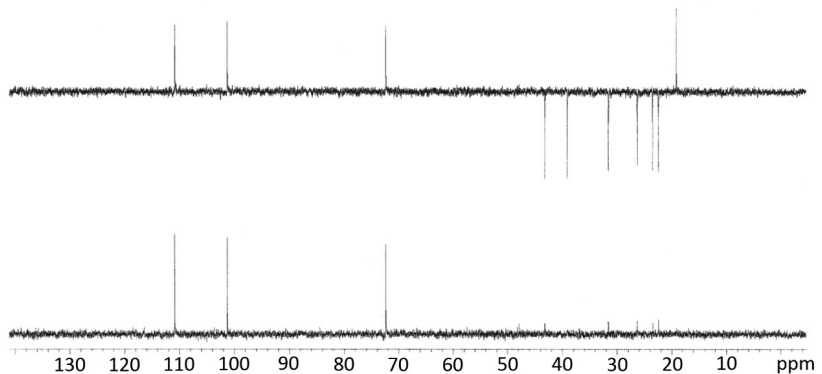

Figure. 2. (A) NMR spectrogram analyses based on curvularin identification in fraction D from an ethyl acetate extract obtained from Cochliobolus sp. G2-20: NMR spectrogram of $1 \mathrm{H}\left(\delta \mathrm{CD}^{3} \mathrm{OD} ; 300 \mathrm{MHz}\right) ;(\mathrm{B}) \mathrm{NMR}$ spectrogram analyses based on curvularin identification in fraction D from an ethyl acetate extract obtained from Cochliobolus sp. G2-20: expansion of ${ }^{1} \mathrm{H}$ Region 2.50-3.50 ppm; (C) NMR spectrogram analyses based on curvularin identification in fraction D from an ethyl acetate extract obtained from Cochliobolus sp. G2-20: spectrum of ${ }^{13} \mathrm{C}\left(\delta \mathrm{CD}^{3} \mathrm{OD} ; 75.5 \mathrm{mHz}\right)$; (D) NMR spectrogram analyses based on curvularin identification in fraction D from an ethyl acetate extract obtained from Cochliobolus sp. G2-20: spectrum of heteronuclear single quantum coherence (HSQC) ( $\delta$ CD $\left.{ }^{3} \mathrm{OD}\right)$; (E) NMR spectrogram analyses based on curvularin identification in fraction D from an ethyl acetate extract obtained from Cochliobolus sp. G2-20: expansion of spectrum by HSQC (region of 20-34 ppm in F1); (F) NMR spectrogram analyses based on curvularin identification in fraction D from an ethyl acetate extract obtained from Cochliobolus sp. G2-20: spectrum of distortionless enhancement by polarization transfer (DEPT) $\left(\delta \mathrm{CD}^{3} \mathrm{OD}\right)$. 
Curvularia, Penicillium, and Alternaria. It has been identified as protein 90 (HSP90) inhibitors. HSP90 is a chaperone that is involved in cell signaling, proliferation, and survival (Aly et al., 2010). Thus, curvularin represents a promising treatment for cancer, as well as a potential antibiotic and herbicide (Jiang et al., 2007; Tilley and Walker 2002).

Initially, this compound was identified as produced by Curvularia sp. and later from Penicillium steckii (Vesonder et al., 1976). Jiang et al. (2007) isolated a similar compound called $\beta$-dehydrocurvularin from the endophytic fungus Curvularia eragrostidis, of interest due to its potential as biological control of the weed Digitaria sanguinalis showing significant inhibitory effect on seed germinations, in addition to causing extensive necrosis in leaves of many known weeds while corn and soybeans remained unaffected; therefore, $\beta$-dehydrocurvularin was considered as a natural bioherbicide (Jiang et al., 2007).

This is the first report in which curvularin was isolated from Cochliobolus endophytic strains. It has already been detected in Curvularia and it has been identified in soil Cochliobolus (Ghisalberti and Rowland 1993).

Five humans pathogenic and one phytopathogenic bacteria were used to test the antibacterial effect of the extracts produced from Cochliobolus sp. G2-20. All metabolic fractions showed some activity against all bacteria. There was significant inhibition of the phytopathogenic bacterium Xanthomonas axonopodis pv. phaseoli and pathogenic bacteria S. typhi, M. luteus, S. aureus and E. coli (Table 2).
Garcia et al. (2012b) observed a significantly positive inhibitory action of the crude metabolic extracts produced by the endophytic Cochliobolus G2-20 against the bacteria M. luteus (ATCC 9341), S. aureus (ATCC 25923), E. coli (ATCC 25922), S. typhi (ATCC 19430), and E. hirae (ATCC 1227). However, in this study, the metabolic fractions isolated from this endophyte did not have an inhibitory effect on E. hirae.

Hormazabal and Piontelli (2009) reports that the metabolite produced by Curvularia protubera, an endophyte from Chilean native gymnosperms, had the greatest inhibitory activity on Bacillus subtilis, M. luteus, and S. aureus, with inhibition zone diameters of 12,9 , and $16 \mathrm{~mm}$, respectively. The metabolites tested by these authors do not present activity against $E$. coli, in contrast to our results.

The metabolic fractions $\mathrm{C}_{\text {crystal }}, \mathrm{D}, \mathrm{EF}$, and I had significant activity against pathogenic fungi $M$. perniciosa, $F$. solani f. sp. Glycines, and D. bryonae (Table 3). There was no inhibition of $S$. sclerotiorum and $C$. gloeosporioides; there was mycelial growth throughout the plate in all treatments except the positive control.

According to Cappelletty and Rybak (1996) and Corning (2000), it is important to pay attention to toxins that are not usual, to be present as isolates in the natural environment. Hence, about the assay of fractions of extracts of fungi, the metabolites could have synergistic effects, with higher action than those produced by each metabolite separately. It is important considering divergent effect of fungal extracts and its metabolic fractions. Cochliobolus species

Table 1. ${ }^{1} \mathrm{H}(300 \mathrm{MHz})$ and ${ }^{13} \mathrm{C}(75.5 \mathrm{MHz}) \mathrm{NRM}\left(\delta \mathrm{CD}_{3} \mathrm{OD}\right)$ spectrum data of fraction $\mathrm{D}$ and of curvularin (Dong et al., 2014).

\begin{tabular}{|c|c|c|c|c|c|}
\hline & \multicolumn{3}{|c|}{ Fraction D } & \multicolumn{2}{|l|}{ Curvularin } \\
\hline $\mathrm{H} / \mathrm{C}$ & DEPT & $\delta_{\mathrm{H}}($ mult.; $\mathrm{J}$ in $\mathrm{Hz}$ ) & $\delta_{\mathrm{C}}$ & $\delta_{\mathrm{H}}($ mult.; $\mathrm{J}$ in $\mathrm{Hz})$ & $\delta_{\mathrm{C}}$ \\
\hline 1 & $\mathrm{C}_{0}$ & - & 172.9 & - & 171.5 \\
\hline \multirow{2}{*}{2} & \multirow{2}{*}{$\mathrm{CH}_{2}$} & $3.86(\mathrm{~d} ; 15.6 \mathrm{~Hz})$ & \multirow{2}{*}{40.86} & $3.62(\mathrm{~d} ; 15,8 \mathrm{~Hz})$ & \multirow{2}{*}{39.1} \\
\hline & & 3.61 (d; $15.9 \mathrm{~Hz})$ & & $3.62(\mathrm{~d} ; 15.8 \mathrm{~Hz})$ & \\
\hline 3 & $\mathrm{C}_{0}$ & - & 137.40 & - & 135.8 \\
\hline 4 & $\mathrm{CH}$ & $6.10(\mathrm{~d} ; 2.1 \mathrm{~Hz})$ & 112.38 & $6.24(\mathrm{~d} ; 2.2 \mathrm{~Hz})$ & 110.9 \\
\hline 5 & $\mathrm{C}_{0}$ & - & 161.41 & - & 159,7 \\
\hline 6 & $\mathrm{CH}$ & $6.24(\mathrm{~d} ; 2.4 \mathrm{~Hz})$ & 102.84 & $6.69(\mathrm{~d} ; 2.2 \mathrm{~Hz})$ & 101.4 \\
\hline 7 & $\mathrm{C}_{0}$ & - & 159.69 & - & 158.2 \\
\hline 8 & $\mathrm{C}_{0}$ & - & 121.01 & - & 119,5 \\
\hline 9 & $\mathrm{C}_{0}$ & - & 209.91 & - & 208.5 \\
\hline \multirow{2}{*}{10} & \multirow{2}{*}{$\mathrm{CH}_{2}$} & $1.58(\mathrm{~m})$ & \multirow{2}{*}{44.79} & & \multirow{2}{*}{43.3} \\
\hline & & $1.45(\mathrm{~m})$ & & & \\
\hline \multirow{2}{*}{11} & \multirow{2}{*}{$\mathrm{CH}_{2}$} & $3.23(\mathrm{dd} ; 2.7 \mathrm{~Hz})$ & \multirow{2}{*}{24.00} & $3.18(\mathrm{ddd} ; 2.7,9.0,15.3)$ & \multirow{2}{*}{22.5} \\
\hline & & $3.18(\mathrm{dd} ; 2.5 \mathrm{~Hz})$ & & 2,75 (ddd; 2.6, 9.6; 15.2) & \\
\hline \multirow{2}{*}{12} & \multirow{2}{*}{$\mathrm{CH}_{2}$} & $1.30(\mathrm{~m})$ & \multirow{2}{*}{27.87} & $1.74(\mathrm{~m})$ & \multirow{2}{*}{26.3} \\
\hline & & $1.20(\mathrm{~m})$ & & $1.55(\mathrm{~m})$ & \\
\hline \multirow{2}{*}{13} & \multirow{2}{*}{$\mathrm{CH}_{2}$} & $1.42(\mathrm{~m})$ & \multirow{2}{*}{25.80} & $1.32(\mathrm{~m})$ & \multirow{2}{*}{23.5} \\
\hline & & $1.28(\mathrm{~m})$ & & $1.44(\mathrm{~m})$ & \\
\hline \multirow[b]{2}{*}{14} & \multirow[b]{2}{*}{$\mathrm{CH}_{2}$} & $1.56(\mathrm{~m})$ & \multirow[b]{2}{*}{33.13} & $1.59(\mathrm{~m})$ & \multirow[b]{2}{*}{31.6} \\
\hline & & $1.46(\mathrm{~m})$ & & $1.45(\mathrm{~m})$ & \\
\hline 15 & $\mathrm{CH}$ & $4.82(\mathrm{~m})$ & 73.94 & $4.91(\mathrm{~m})$ & 72.2 \\
\hline $\mathrm{CH}_{3}-15$ & $\mathrm{CH}_{3}$ & $1.12(\mathrm{~d} ; 6.3 \mathrm{~Hz})$ & 20.64 & $1.12(\mathrm{~d} ; 6.4 \mathrm{~Hz})$ & 19.1 \\
\hline
\end{tabular}


Table 2. Size of inhibition zone ( $\mathrm{mm}$ ) generated by fractions of metabolites of endophytic Cochliobolus $\mathrm{sp}$. G2-20 on phytopathogenic and human pathogenic bacteria. The experiment was performed in triplicate. Data are mean \pm standard deviation.

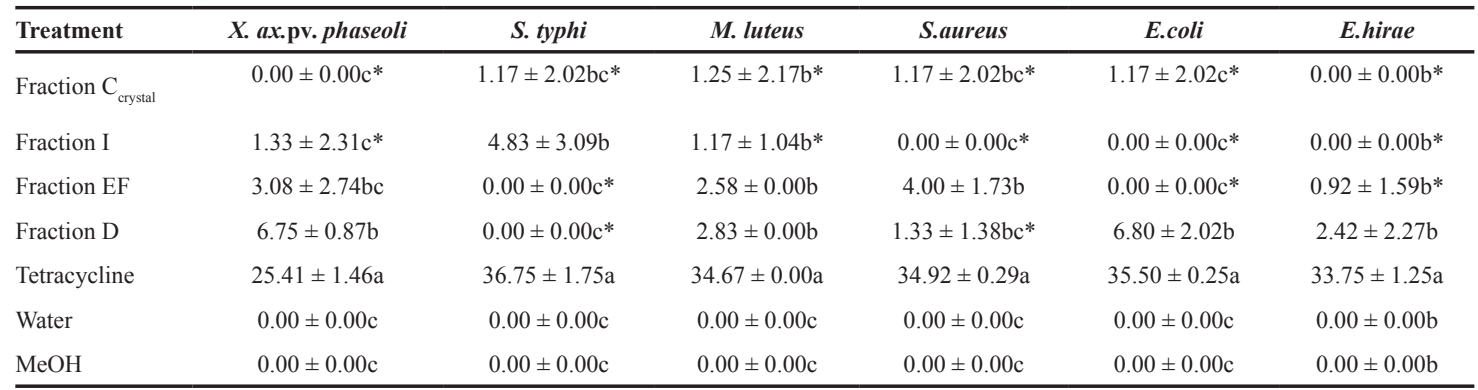

Means followed by different letters ( $\mathrm{a}, \mathrm{b}$, and $\mathrm{c}$ ) in the column are significantly different (Tukey's test; $\mathrm{p}<0.05$ ). Water and MeOH: negative control, Tetracycline: positive control. $*=p$-value $>0.05$ compared with negative controls.

Table 3. Antifungal activity of metabolites of the endophyte Cochliobolus sp. G2-20. Data are the average mycelial growth $(\mathrm{mm})$ measured on day 7 of fungal pathogens treated with fractions of metabolites. The experiment was performed in triplicate.

Data are mean \pm standard deviation.

\begin{tabular}{lccccc}
\hline Treatment & C. gloeosporiodes & M. perniciosa & D. bryonae & F. solani f. sp. glycines & S. sclerotiorum \\
\hline Water & $4.50 \pm 0.66 \mathrm{a}$ & $5.00 \pm 0.00 \mathrm{a}$ & $4.37 \pm 0.14 \mathrm{a}$ & $4.10 \pm 0.10 \mathrm{a}$ & $4.63 \pm 0.15 \mathrm{a}$ \\
MeOH & $4.40 \pm 0.60 \mathrm{a}$ & $5.00 \pm 0.00 \mathrm{a}$ & $4.30 \pm 0.00 \mathrm{a}$ & $4.20 \pm 0.00 \mathrm{a}$ & $4.60 \pm 0.00 \mathrm{a}$ \\
Derosal & $3.10 \pm 0.25 \mathrm{~b}$ & $3.47 \pm 0.12 \mathrm{~d}$ & $3.00 \pm 0.10 \mathrm{~b}$ & $2.47 \pm 0.15 \mathrm{c}$ & $3.00 \pm 0.10 \mathrm{~b}$ \\
Fraction D & $4.40 \pm 0.36 \mathrm{a}^{\#}$ & $4.40 \pm 0.17 \mathrm{bc}$ & $2.97 \pm 1.14 \mathrm{~b} * \# \%$ & $2.73 \pm 0.64 \mathrm{bc} \mathrm{c}^{* *} \%$ & $4.50 \pm 0.10 \mathrm{a}^{* \#}$ \\
Fraction EF & $4.23 \pm 0.25 \mathrm{a}^{\#}$ & $4.23 \pm 0.07 \mathrm{c}$ & $1.63 \pm 0.07 \mathrm{c}$ & $3.03 \pm 0.25 \mathrm{bc}$ & $4.50 \pm 0.00 \mathrm{a}^{* \#}$ \\
Fraction I & $4.50 \pm 0.00 \mathrm{a}^{* \#}$ & $4.40 \pm 0.17 \mathrm{bc}$ & $1.33 \pm 0.07 \mathrm{c}$ & $2.83 \pm 0.12 \mathrm{bc}$ & $4.60 \pm 0.10 \mathrm{a}^{* \#}$ \\
Fraction C & $4.47 \pm 0.06 \mathrm{a}^{* \#}$ & $4.50 \pm 0.00 \mathrm{~b}$ & $1.57 \pm 0.15 \mathrm{c}$ & $2.70 \pm 0.00 \mathrm{c}^{*}$ & $4.57 \pm 0.06 \mathrm{a}^{* \#}$ \\
CV $(\%)$ & 26.51 & 1.99 & 15.84 & 9.14 & 2.55 \\
\hline
\end{tabular}

Means followed by different letters (a, b, and c) in a column are significantly different (Tukey's test; $p<0.05$ ). Water and MeOH: negative control, Derosal: positive control. $\mathrm{CV}(\%)$ : coefficient of variation. ${ }^{*}=p$-value $>0.05$ compared with Water control, ${ }^{*}=p$-value $>0.05$ compared to $\mathrm{MeOH}$ control, ${ }^{\%}=p$-value $>0.05$ compared with Derosal control.

have been used for the biological control of plague grasses, such as crabgrass. Where the fungus was applied, grasses displayed typical disease symptoms like death or reduced growth. This fungus can be applied directly to the leaves, and the inclusion of additives such as glucose-based surfactants or starch may improve the action of the fungus (Tilley and Walker 2002).

\section{CONCLUSION}

The endophytic fungus Cochliobolus sp. G2-20, isolated from leaves of the plant $S$. saponaria produces metabolites, largely curvularin, a plant and fungal compound also produced by endophytic fungi of the genus Curvularia. The fraction C and D that contained curvularin has showed antifungal and antibacterial properties.

\section{ACKNOWLEDGMENTS}

To CNPq (307603/2017-2), SETI/UGF (TC n.65/2018), and to Coordenação de Aperfeiçoamento de Pessoal de Nível Superior - Brazil (CAPES - Finance code 001) for scholarships.

\section{REFERENCES}

Aly AH, Debbab A, Edrada-Ebel RA, Müller WEG, Kubbutat MHG, Wray V, Ebel R, Proksch P. Protein kinase inhibitors and other cytotoxic metabolites from the fungal endophyte Stemphylium botryosum isolated from Chenopodium album. Mycosphere, 2010; 1:153-62.

Arnold AE, Mejía LC, Kyllo D, Rojas EI, Maynard Z, Robbins N, Herre EA. Fungal endophytes limit pathogen damage in tropical tree. Proc Natl Acad Sci, 2003; 100:15649-15654.
Azevedo JL, Maccheroni WJ, Pereira JO, Araujo WL. Endophytic microorganisms: a review on insect control and recent advances on tropical plants. Elect J Biotechnol, 2000; 3:40-65.

Bernardi-Wenzel J, Garcia A, Rubin-Filho CJ, Prioli AJ, Pamphile JA. Evaluation of foliar fungal endophyte diversity and colonization of medicinal plant Luehea divaricata (Martius et Zuccarini). Biol Res, 2010; 43:375-84.

Campos FF, Rosa LH, Cota BB, Caligiorne RB, Rabello ALT, Alves TMA, Rosa CA, Zani CL. Leishmanicidal metabolites from Cochliobolus sp., an endophytic fungus isolated from Piptadenia adiantoides (Fabaceae). PLOS Negl Trop Dis, 2008; 2:1-10.

Cappelletty DM, Rybak MJ Comparison of methodologies for synergism testing of drug combinations against resistant strains of Pseudomonas aeruginosa. Antimicrob. Agents Chemother, 1996; 40:677-83.

Chagas FO, Caraballo-Rodriguez M, Pupo AM. Endophytic fungi as a source of novel metabolites. In: Martín J, Garcia-Estrada C, Zellinger S (eds.). Biosynthesis and molecular genetics of fungal secondary metabolites, Springer, New York, 2015.

Corning PA. "The synergism hypothesis": on the concept of synergy and its role in the evolution of complex systems. J Soc Evol Sys, $2000 ; 21: 133-72$.

Dong J, Zhao L, Cai L, Fang H, Chen X, Ding Z. Antioxidant activities and phenolics of fermented Bletilla formosana with eight plan pathogen fungi. J Biosci Bioeng, 2014; 118:396-99.

Ferreira DF. Sisvar: a computer analysis system. Ciênc Agrotec, $2011 ; 35: 1039-42$.

Firáková S, Sturdíková M, Múcková M. Bioactive secondary metabolites produced by microorganisms associated with plants. Biologia 2007; 62:01-6. 
Flores AC, Pamphile JA, Sarragiotto MH, Clemente E. Production of 3-nitropropionic acid by endophytic fungus Phomopsis longicolla isolated from Trichilia elegans A. Juss ssp. Elegans and evaluation of biological activity. World J Microbiol Biotechnol, 2013; 28:923-32.

Garcia A, Rhoden SA, Rubin-Filho CJ, Nakamura CV, Pamphile JA. Diversity of foliar endophytic fungi from the medicinal plant Sapindus saponaria $\mathrm{L}$. and their localization by scanning electron microscopy. Biol Res, 2012a; 45:139-148.

Garcia A, Rhoden SA, Bernardi-Wenzel J, Orlandelli RC, Azevedo JL, Pamphile JA. Antimicrobial activity of crude extracts of endophytic fungi isolated from the medicinal plant Sapindus saponaria L. J App Pharm, 2012b; 2(10):35-40.

Gazis R, Chaverria P. Diversity of fungal endophytes in leaves and stems of wild rubber trees (Hevea brasiliensis) in Peru. Fungal Ecol, 2010; 3:240-54.

Ghisalberti EL, Rowland CY. 6-Chlorodehydrocurvularin, a new metabolite from Cochliobolus spicifer. J Nat Prod, 1993; 56:2175-7.

Gomes-Figueiredo J, Pimentel IC, Vicente VA, Pie MR, KavaCordeiro V, Galli-Terasawa LPJO, Pereira JO, de Souza AQL, Glienke C. Bioprospecting highly diverse endophytic Pestalotiopsis spp. with antibacterial properties from Maytenus ilicifolia, a medicinal plant from Brazil. Can J Microbiol, 2007; 53:1123-32.

Hormazabal E, Piontelli E. Endophytic fungi from Chilean native gymnosperms: antimicrobial activity against human and phytopathogenic fungi. World J Microbiol Biotechnol, 2009; 25:813-9.

Jiang SJ, Qiang S, Zhu YZ, Dong YF. Isolation and phytotoxicity of a metabolite from Curvularia eragrostidis and characterisation of its modes of action. Ann Appl Biol, 2007; 152:103-111.

Kaneko T, Minamisawa K, Isawa T, Nakatsukasa H, Mitsui $\mathrm{H}$, Kawaharada Y, Nakamura Y, Watanabe A, Kawashima K, Shimizu AOY, Takahashi C, Minami C, Fujishiro T, Kohara M, Katoh M, Nakazaki N, Nakayama S, Yamada M, Tabata S, Sato S. Complete genomic structure of the cultivated rice endophyte Azospirillum sp. B510. DNA Res, 2010; 17:37-50.

Kusari S, Hertweck C, Spiteller M. Chemical ecology of endophytic fungi: origins of secondary metabolites. Chem Biol, 2012; 19:792-8.

Larran S, Perelló A, Simón MR, Moreno V. The endophytic fungi from wheat (Triticum aestivum L.). World J Microbiol Biotechnol, $2007 ; 23: 565-72$.

Manamgoda DS, Cai L, Bahkali AH, Chukeatirote E, Hyde KD. Cochliobolus: an overview and current status of species. Fungal Divers, 2011; 51:3-42.

Mejía LC, Rojas EI, Maynard Z, Bael SV, Aenold AE, Hebbar P, Samuels GJ, Robins N, Herre EA. Endophytic fungi as biocontrol agents of Theobroma cacao pathogens. Biol Control, 2008; 46:4-14.

Orlandelli RC, Alberto RN, Rubin-Filho CJ, Pamphile JA. Diversity of endophytic fungal community associated with Piper hispidum Sw. (Piperaceae) leaves. Genet Mol Res, 2012; 11:1575-85.

Ramasamy K, Lim SM, Bakar HA, Ismail N, Ismail MS, Ali MF, Weber JFF, Cole ALJ. Antimicrobial and cytotoxic activities of Malaysian endophytes. Phytother Res, 2010; 24:640-3.
Romão-Dumaresq A S, Dourado MN, de Fávaro LCL, Mendes R, Ferreira A, Araújo WL. Diversity of cultivated fungi associated with conventional and transgenic sugarcane and the interaction between endophytic Trichoderma virens and the host plant. PLoS One, 2016; 11:129.

Rukachaisirikul V, Sommart U, Phongpaichit S, Sakayaroj J, Kirtikara K. Metabolites from the endophytic fungus Phomopsis sp. PSU-D15. Phytochemistry, 2008; 69:783-7.

Sambrook J, Russel LDW. Molecular cloning: a laboratory manual. 3rd edition, Cold Spring Harbor Laboratory Press, New York, 2001.

Schulz B, Boyle C, Draeger S, Römmert A, Krohn K. Endophytic Fungi: a source of novel biologically active secondary metabolites. Mycol Res, 2002; 106:996-1004.

Specian V, Sarragiotto MH, Pamphile JA, Clemente E. Chemica characterization of bioactive compounds from the endophytic fungus Diaporthe helianthi isolated from Luehea divaricate. Brazilian J Microbiol, 2012; 43:1174-82.

Strobel G, Daisy B, Castillo U, Harper J. Natural products from endophytic microorganisms. J Nat Prod, 2004; 67:257-68.

Suryanarayanan TS, Murali TS, Venkatesan G. Occurrence and distribution of fungal endophytes in tropical forests across a rainfal gradient. Can J Bot, 2002; 2:25-37.

Terhonen E, Sipari N, Asiegbu FO. Inhibition of phytopathogens by fungal root endophytes of Norway spruce. Biol Control, 2016; 99:53-63.

Thongkantha S, Lumyong S, McKenzie EHC, Hyde KD. Fungal saprobes and pathogens occurring on tissues of Dracaena lourieri and Pandanus spp. in Thailand. Fungal Divers, 2008; 30:149-69.

Tilley AM, Walker HL. Evaluation of Curvularia intermedia (Cochliobolus intermedius) as a potential microbial herbicide for large crabgrass (Digitaria sanguinalis). Biol Control, 2002; 25:12-21.

Vesonder RF, Ciegler A, Fennell D, Tjarks LW, Jensen AH. Curvularin from Penicillium baradicum Baghdadi NRRL 3754, and biological effects. J Environ Sci Health, 1976; 11:289-97.

Yan JM, Wang X, Tian MQ, Liu CM, Zhang KQ, Li GH. Chemical constituents from the fungus Stereum sp. YMF1.04183. Phytochem Lett, 2017; 22:6-8

Ye X, Anjum k, Song T, Wang W, Yu S, Huang H, Lian XY, Zhang Z. A new curvularin glycoside and its cytotoxic and antibacterial analogues from marine actinomycete Pseudonocardia sp. HS7. Nat Prod Res, 2015; 30:1-6.

How to cite this article:

Ataides D, Pamphile JA, Garcia A, Ribeiro MAS, Polonio JC, Sarragiotto MH, Clemente E. Curvularin produced by endophytic Cochliobolus sp. G2-20 isolated from Sapindus saponaria L. and evaluation of biological activity. J App Pharm Sci, 2018; 8(12): 032-037. 